\title{
Biology and Management of the Bermudagrass Mite, Eriophyes cynodoniensis ${ }^{1}$
}

\author{
Pablo Agustin Boeri, Nicole D. Benda, J. Bryan Unruh, and Adam Dale²
}

\section{Introduction}

The bermudagrass mite, Eriophyes cynodoniensis (Sayed) (Arthropoda: Arachnida: Eriophyidae), also known as the couch grass mite, can be a serious pest of bermudagrass (Cynodon dactylon [L.] Pers.) in multiple high-maintenance turf systems such as sod production, athletic fields, and golf courses (Buss 2008). Like most eriophyid mite species, the bermudagrass mite specializes on one host plant and thus does not attack other plant species. Mites in the family Eriophyidae are commonly known to cause leaf and bud galls on their host plants, which can lead to severe aesthetic damage and plant decline or death in high-maintenance areas with low tolerance for plant damage (Figure 1).

Another less widely distributed and problematic eriophyid mite species, Eriophyes cynodonis (Wilson), can also be found on bermudagrass in the United States. However, most recent documentation indicates that this mite has only been found in California, Kansas, and Arkansas (Jeppson et al. 1975). These mites are typically located feeding within the folded terminal foliage. Heavy infestations can inhibit leaf expansion and generate a characteristic twisting of the folded shoot and leaf blade (Wilson 1959). Importantly for initial differentiation, E. cynodonis does not produce the witch's brooming damage associated with E. cynodoniensis outbreaks (Figure 2). Other eriophyid mite species may also be confused with E. cynodoniensis. The zoysiagrass mite,

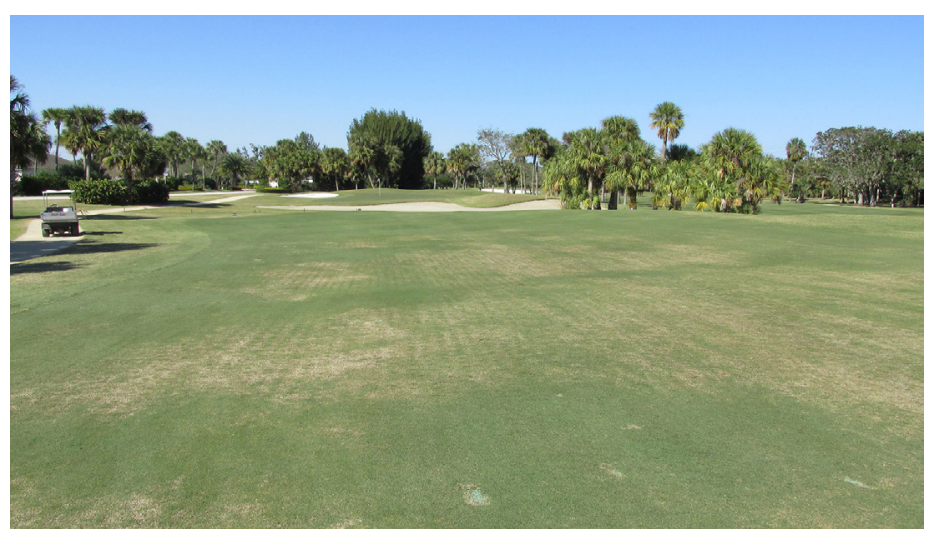

Figure 1. Brown patches of thinning bermudagrass observed from a distance caused by bermudagrass mite on a Florida golf course.

Credits: Craig Weyandt, GCS

Eriophyes zoysiae, causes similar damage, but generally less yellowing of the foliage, and, most importantly, damages only zoysiagrass species and cultivars (Wilson 1959, Baker et al. 1986).

\section{Synonymy}

Although bermudagrass mite is the officially recognized common name of E. cynodoniensis, it may also be referenced in various older resources as the couch grass mite or bermudagrass stunt mite.

1. This document is ENY-342, one of a series of the Department of Entomology and Nematology, UF/IFAS Extension. Original publication date July 2018. Visit the EDIS website at http://edis.ifas.ufl.edu.

2. Pablo Agustin Boeri, graduate student, UF/IFAS West Florida Research and Education Center; Nicole D. Benda, post-doctoral associate, UF/IFAS WFLREC; J. Bryan Unruh, professor and associate center director, UF/IFAS WFLREC; and Adam Dale, assistant professor, Department of Entomology and Nematology; UF/IFAS Extension, Gainesville, FL 32611.

The Institute of Food and Agricultural Sciences (IFAS) is an Equal Opportunity Institution authorized to provide research, educational information and other services

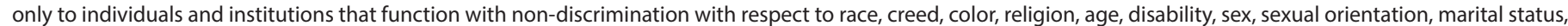

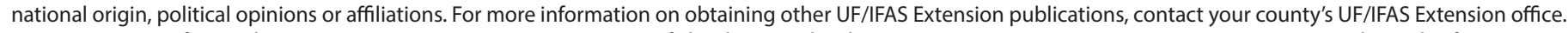
U.S. Department of Agriculture, UF/IFAS Extension Service, University of Florida, IFAS, Florida A \& M University Cooperative Extension Program, and Boards of County Commissioners Cooperating. Nick T. Place, dean for UF/IFAS Extension. 


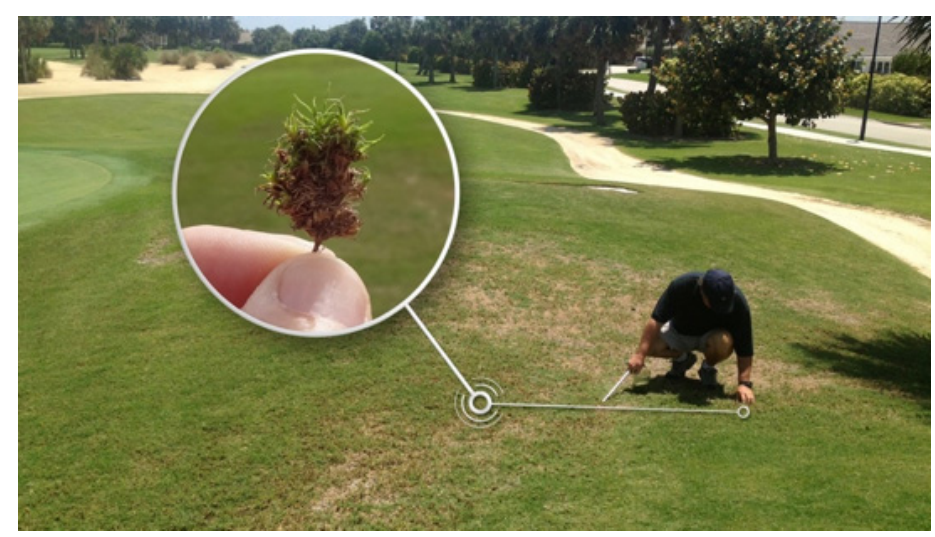

Figure 2. Characteristic damage on 'Celebration' bermudagrass heavily infested with bermudagrass mite on a Florida golf course.

Credits: Todd Lowe, United States Golf Association (USGA)

\section{Scientific Synonyms}

Aceria cynodoniensis Sayed, 1946 (Reinert 1983)

Aceria neocynodonis Keifer, 1960 (Watschke et al. 1995)

Eriophyes cynodoniensis Sayed (Jeppson et al. 1975), the currently accepted valid name

\section{Distribution}

Bermudagrass mite is believed to be native to Africa, where most bermudagrass species are also native (Beehag 1992; Jeppson et al. 1975). Currently, it can be found across the globe, including New Zealand, Africa, and North America (Jeppson et al. 1975). In North America, this mite was discovered for the first time infesting bermudagrass lawns in Phoenix, Arizona, in 1959 (Butler 1963). It has since dispersed to California, Nevada, New Mexico, Oklahoma, Texas, Georgia, South Carolina, North Carolina, and Florida (Denmark 1964). Although it has recently become more problematic in Florida, the bermudagrass mite is an old problem, first reported in the state in 1962 and rapidly spreading across the entire state (Johnson 1975).

Scouting for bermudagrass mites is difficult due to their small size and habit of feeding within tight leaf growth, where they are protected from natural enemies and environmental conditions. Therefore, the best way to identify a suspected bermudagrass mite infestation is to scout for the damage (Figure 2). Once damaged plant material is found, the best method for confirming an infestation is to submit a sample to the UF/IFAS Insect Diagnostics Lab (http:// entnemdept.ufl.edu/insectid/). Remove the symptomatic growth, submerge it in ethanol (hand sanitizer or rubbing alcohol), place it in a sealed container, and mail or deliver to the Insect Diagnostics Lab following their recommended sample submission procedures.

\section{Description}

Mites in the family Eriophyidae make up most gall-making mite species. Eriophyids are the smallest arthropods that feed on plants (Sabelis and Bruin 1996). The most distinguishing characteristics of these mites is their highly elongated sickle or banana-shaped abdomen and their two pairs of forward-facing legs, unlike most mites, which have four pairs of legs (Jeppson 1975). Other key features of mites within this family are drastically shortened mouthparts, called "oral stylets." These mites often have several hair-like structures called tubercles and setae located along their backs, although this varies between species (Jeppson et al. 1975).

Eriophyes cynodoniensis is extremely small (about 165 to $210 \mu \mathrm{m}$ long) and creamy-yellowish-white in color. Due to their extremely small size, a magnifying lens or microscope is needed to see them (Figure 3). Eriophyes cynodoniensis undergoes a form of incomplete metamorphosis that includes four life stages: egg, protonymph, deutonymph, and adult.

Figure 3. Compound light microscope image of a mature bermudagrass mite, Eriophyes cynodoniensis.

Credits: J. L. Castner, UF/IFAS

\section{Egg}

Adult female E. cynodoniensis mites can produce approximately 50 eggs per individual (Jeppson et al. 1975). Eggs are deposited underneath bermudagrass leaf sheaths and usually hatch in 2 to 3 days. Eggs are round, whiteto-translucent, and approximately $0.06 \mathrm{~mm}$ in diameter (Watschke et al. 1995).

\section{Nymph}

Bermudagrass mite nymphs undergo two instars or developmental stages. Nymphs resemble adults, but they are more translucent and much smaller. Nymphs have two pairs of short legs attached to the broad end of their banana-shaped body (Figure 3). The abdomen has minute rings that run perpendicular to the body and resemble segments. Between the first and second instar, nymphs 
undergo an inactive period similar to a pupa, called the "nymphochrysalis" (Sternhcht 1971; Jeppson et al. 1975). The second-instar nymph is approximately $0.12 \mathrm{~mm}$ long and creamy white when fully developed (Watschke et al. 1995). The second-instar nymph also has a resting period before becoming an adult, called the "imagochrysalis" (Sternhcht 1971; Jeppson et al. 1975).

\section{Adult}

Females are approximately $0.2 \mathrm{~mm}$ long. Both males and females have a characteristic structure at the ends of their legs that resembles a claw covered with hairs. These features are called "featherclaws" and are a key trait for identification between different mite species and sexes. The distinctive two pairs of legs are thick and short, and the last region of the abdomen has approximately 60 rings (Jeppson et al. 1975).

\section{Life Cycle}

One generation (development from egg to adult) takes between 5 and 14 days, depending on time of year and local weather conditions. Bermudagrass mites are most active through spring and early summer, but in tropical regions like southern Florida, they can be found year-round. This mite seems to be tolerant of high temperatures $\left(120^{\circ} \mathrm{F}\right.$ $\left[49^{\circ} \mathrm{C}\right]$ ), and cool weather slows its development (Watschke et al. 1995). During unfavorable conditions and cool seasons, most eriophyids can diapause and find refuges to survive until temperatures warm and daylight lengthens (Jeppson et al. 1975). The bermudagrass mite spends most of its life protected inside the leaf sheath, and up to 200 individuals can occur within this region on the plant (Figure 4) (Buss 2008).

As with many other mite species, E. cynodoniensis disperses passively. Most commonly, mites drift on air currents, but sometimes they end up on other organisms (e.g., birds or insects) or on grass clippings (Jeppson et al. 1975). Interestingly, this mite species is said to be capable of dispersing by hitching a ride on migrating mole crickets (Cromroy 1983). Importantly, bermudagrass mites cannot survive on bermudagrass seed. Therefore, bermudagrass propagation via seed may have a lower infestation risk than vegetative propagation methods, although vegetative propagation has several other advantages compared to seed propagation.

\section{Hosts and Pest Significance}

As the common name suggests, bermudagrass mite is a specialist on bermudagrass (http://edis.ifas.ufl.edu/lh007). Bermudagrass is a common name for the genus Cynodon

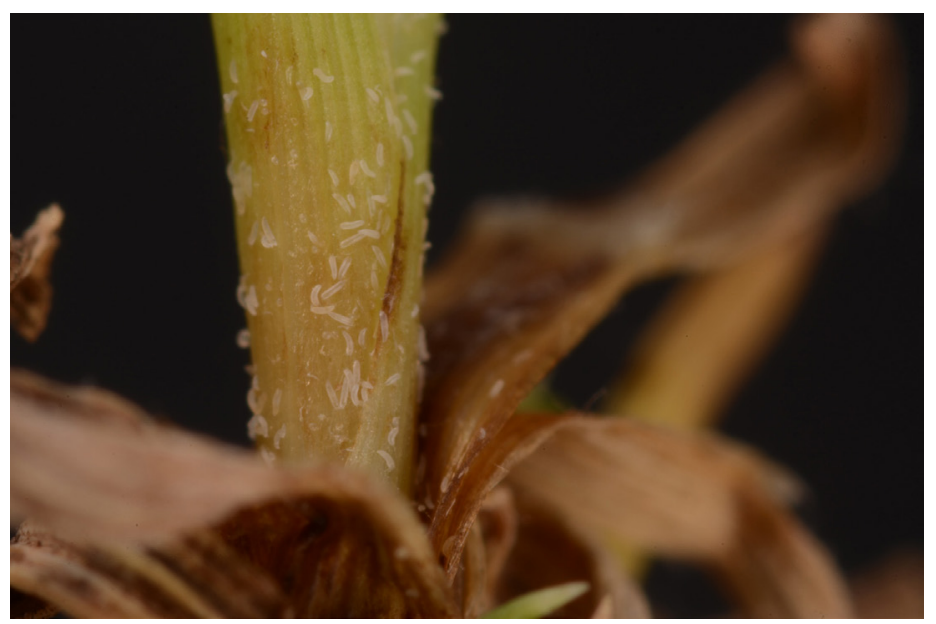

Figure 4. Bermudagrass mites infesting bermudagrass revealed beneath the leaf sheath.

Credits: Lyle Buss, UF/IFAS

(L.) Rich. The genus Cynodon belongs to the family Poaceae and includes nine species. Cynodon dactylon is the most commonly used species, containing fine texture types used for turfgrasses and robust plants with high biomass production used for pastures (Casler 2003). Its common name varies regionally around the world (e.g., "Gramilla" in Argentina, "Doobgrass" in India, "Kweekgrass" in South Africa). Bermudagrass is a perennial, warm season grass primarily used in tropical or subtropical regions of the world, but can also be found in warmer temperate locations. It has excellent tolerance to heat, drought, and heavy foot traffic. In recent decades, the higher quality bermudagrasses used on athletic fields or golf courses have been hybrids between C. dactylon and C. transvaalensis. Examples of these bermudagrass cultivars include, Tifway, Tifsport, Tifdwarf, Midlawn, Midiron, TifEagle, and Champion (Christians 2017).

The turfgrass industry in the United States contributes significantly to the national economy. The most representative sectors of the industry include sod farms, lawncare services, lawn and garden retail stores, lawn equipment manufacturing, golf courses, and athletic fields. These six sectors generated a total revenue of $\$ 57.9$ billion in 2002 and provided 822,849 jobs (Haydu et al. 2006). Bermudagrass is currently the most widely used turfgrass genera around the world and occupies a significant portion of the US athletic field, golf course, and lawn care industries. Because these industries highly maintain their turf to preserve aesthetic quality, growth uniformity, and safe playing conditions, there is a low tolerance for damage associated with bermudagrass mites.

Low-cut turf damaged by bermudagrass mites is not suitable for play and may increase the risk of injury to athletes. Sod farms that are producing bermudagrass may 
also suffer economic losses if grass being grown from sprigs or plugs becomes damaged during the establishment period because this reduces sod quality and increases the time to harvest. Golf courses afflicted with bermudagrass mite infestations struggle with reduced quality of play, which can negatively affect business. Currently, the most effective and primary method for controlling these pests is chemical control, which can be expensive and, in many cases, cost-prohibitive.

\section{Damage}

Plants affected by eriophyid mites show a range of symptoms from complete defoliation and gradual plant death to various types of tissue modification. Eriophyid mites feed on succulent plant tissue and generally cause plant galls, or modified clusters of plant tissue, to protect themselves and to act as a nutrient source. After the mites induce plant cells to change, they do not always remain in the damaged site, which can make detection difficult.

Rather than causing direct feeding damage, bermudagrass mites inject plant growth hormones from their salivary secretions into the plant tissue, which inhibits cell growth and leads to distorted new growth (Salisbury and Ross 1985). The most characteristic symptom of bermudagrass mite outbreaks is called rosetting or tufting, where leaf tips of infested grass lose their color, and internodes become shortened and stunted so that small clumps form (Figure 5). These tufts of plant growth tend to form at the tips of stolons that have not rooted into the soil. Large areas may die (Figures 1 and 2) and become infested with weeds. In general, bermudagrass mite populations and their associated plant damage tend to flare during early spring and into early summer throughout Florida.

\section{Management}

Due to the low success rate associated with reducing heavy bermudagrass mite infestations, an integrated approach using multiple strategies to manage this pest is critical.

\section{Cultural Control}

Correct maintenance practices following UF/IFASrecommended best management practices (BMPs) like proper fertilization, mowing, and irrigation will promote a healthy and vigorously growing stand of bermudagrass, which should reduce the risk of mite damage (http://edis. ifas.ufl.edu/lh007). Although recycling grass clippings is generally recommended, this is not the case if you suspect a bermudagrass mite infestation (more detail in "Mechanical Control" below).

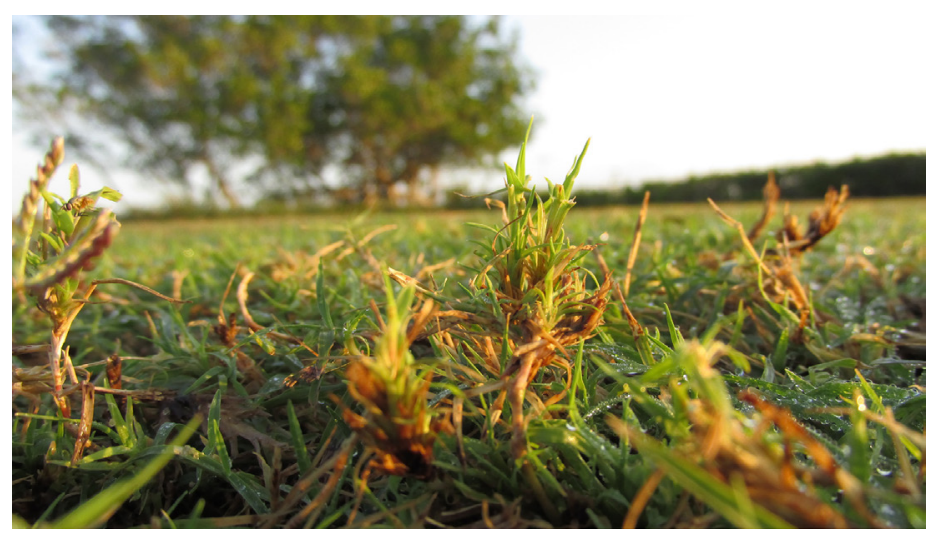

Figure 5. Characteristic tufting damage to 'Celebration' bermudagrass shoots in a heavily-infested golf course fairway.

Credits: Craig Weyandt, GCS

One of the best cultural control strategies is the use of resistant bermudagrass cultivars. Resistant cultivars have been identified in various studies and include: Cardinal, Midlawn, Tifsport, FloraTex, Tifdwarf, and Midiron (Reinert et al. 1978, Reinert et al. 2008). Cultivars recognized as susceptible to this pest and highly symptomatic include: FloraDwarf, Ormond, Tifdwarf, TifEagle, Tifgreen, Tiflawn, and Celebration. 'Tifway' has demonstrated susceptibility and resistance in different tests, so it may be considered intermediate in susceptibility (Buss 2008).

\section{Mechanical Control}

When severe infestations are detected, mowing as low as possible (scalping the turf) and collecting and disposing of grass debris away from the site can reduce bermudagrass mite populations and subsequent damage. Afterwards, minimize turf stress and promote rapid regrowth by watering the area for several days. UF/IFAS research has found that simply scalping and removing infested bermudagrass clippings can reduce bermudagrass mite damage by $50 \%$ from the time of mowing to 28 days later when the turf has regrown (Figure 6). However, this is more effective when done during late spring compared to early spring.

\section{Chemical Control}

Due to their small size and protected feeding behavior, chemical control of bermudagrass mites is difficult. Applications when mites are not fully developed are most likely to be more effective. However, it is not feasible or practical to determine the life stage of these mites because they cannot be seen without magnification and aggressive scouting. Miticides are more effective at controlling mite pests than insecticides because mites are physiologically different from insects. Several studies have demonstrated that insecticides, including imidacloprid and pyrethroids, can worsen spider mite outbreaks by increasing their reproductive output or killing off natural predators (Szczepaniec and Raupp 2012). Therefore, it is important to consider potential unintended 


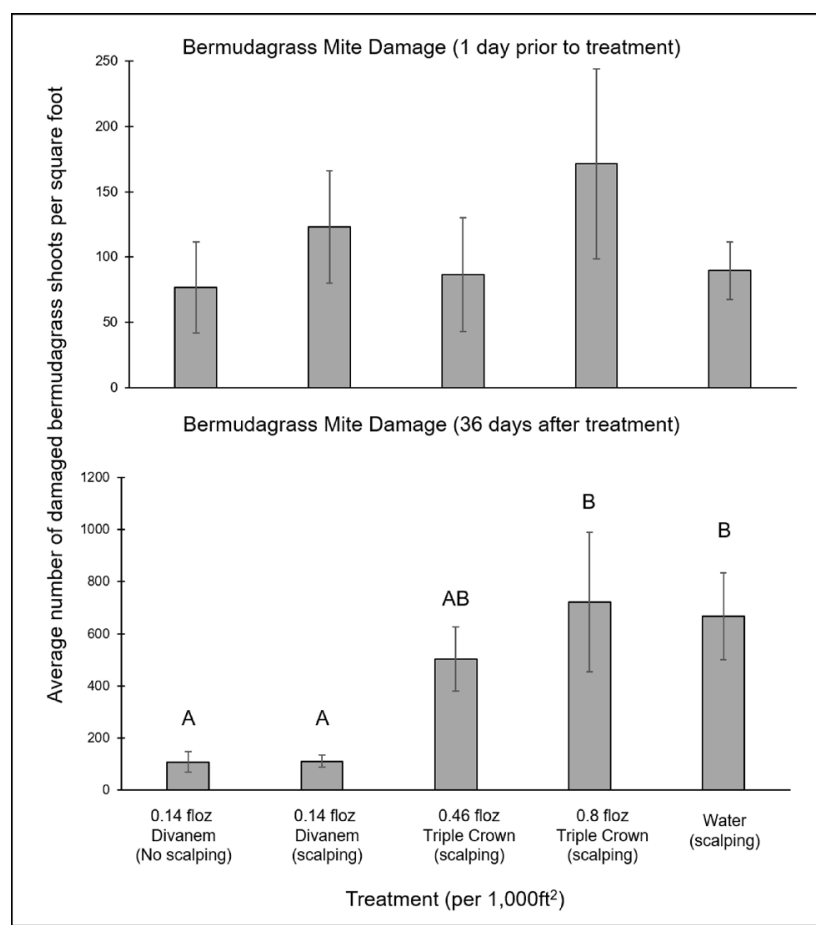

Figure 6. UF/IFAS pesticide efficacy trial conducted in early spring to evaluate the effect of abamectin (Divanem) with and without scalping turf before application, and a combination of imidacloprid, bifenthrin, and z-cypermethrin at two rates with scalping turf. Application rates are per 1,000 $\mathrm{ft}^{2}$ and water was used as an untreated control. Different letters above bars indicate statistical differences.

effects of insecticides before using them. In fact, recent UF/ IFAS research has found that applying a combination of imidacloprid, bifenthrin, and z-cypermethrin to control for bermudagrass mites provided no reduction in mite damage over five weeks (Figure 7). Unfortunately, there are few chemical control options labeled for this pest in turfgrasses, and even fewer on sod farms or residential landscapes.

Any chemicals applied targeting bermudagrass mites require thorough coverage using approximately 2 gallons per $1,000 \mathrm{ft}^{2}$. The current UF/IFAS management recommendation is to apply chemical control immediately after the turfgrass is scalped and clippings are removed. This exposes any remaining mites to the applied chemical, maximizing toxicity. Although most product labels recommend watering in immediately after application, keep in mind these pests are located in the foliage, so only light irrigation (0.25 inches or less) is recommended. Reapplication within two weeks will increase control. Insecticides and miticides labeled for bermudagrass mite control are listed below in Table 1.

Recent UF/IFAS research has evaluated different active ingredients and application rates to determine the best control tactics for managing bermudagrass mite. Evaluated products include abamectin (trade name, Divanem), chlorpyrifos (trade name, Dursban), and a combination of imidacloprid, bifenthrin, and z-cypermethrin (trade

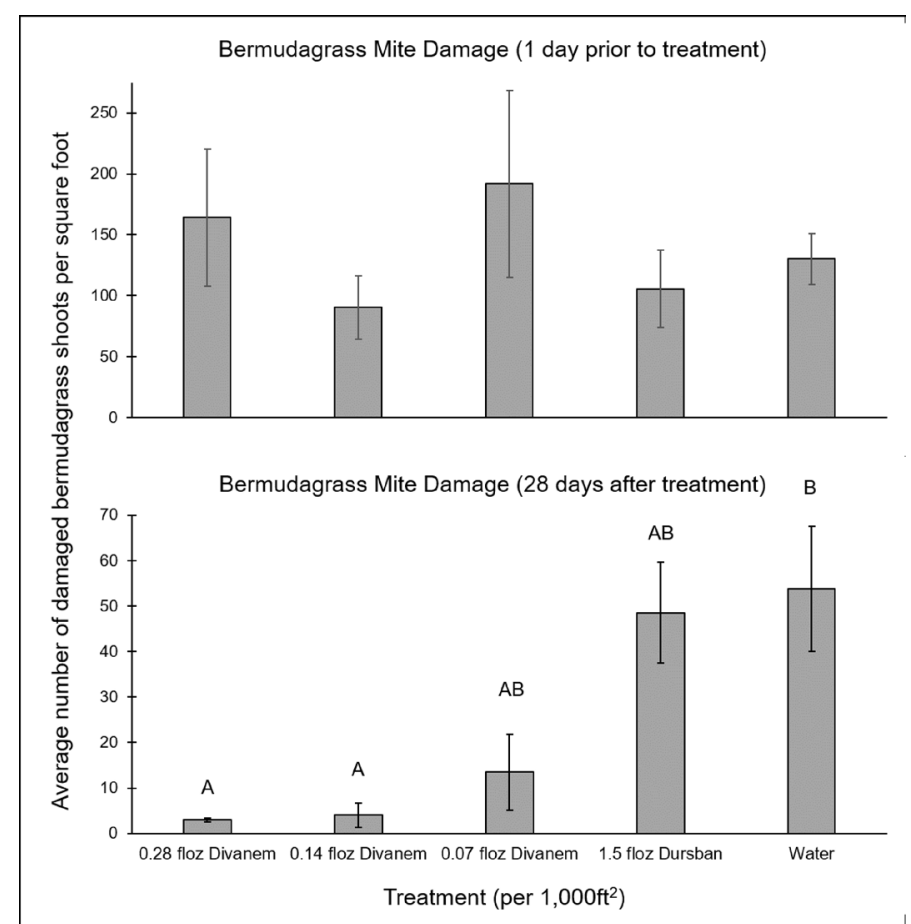

Figure 7. UF/IFAS pesticide efficacy trial conducted in late spring/ early summer, evaluating the effect of abamectin (Divanem) at three application rates compared to chlorpyrifos (Dursban) and a water control. All turf plots were scalped before application. Application rates are per 1,000 $\mathrm{ft}^{2}$ and water was used as an untreated control. Different letters above bars indicate statistical differences.

name, Triple Crown), in addition to the mechanical removal of infested plant material by scalping with no chemical application. Results indicate that abamectin most effectively reduces bermudagrass mite damage within a 28- to 36-day period. Best control was observed after two, 14-day-interval applications of abamectin at $0.14 \mathrm{fl} \mathrm{oz}$ plus $3 \mathrm{fl} \mathrm{oz} \mathrm{Hydro-90}$ (surfactant) per 1000 square feet. We evaluated abamectin at $0.28 \mathrm{fl} \mathrm{oz}$ with $6 \mathrm{fl} \mathrm{oz} \mathrm{Hydro-90}$ per 1000 square feet but observed slight phytotoxic effects and no additional reduction in bermudagrass mite damage. When a combination of imidacloprid, bifenthrin, and z-cypermethrin was applied, we observed no reduction in bermudagrass mites compared to the untreated control plots (Figure 6).

In one trial conducted in early spring, we found no benefit of scalping the turf (Figure 6), but in a second trial conducted in late spring/early summer, scalping reduced mite damage by $50 \%$ ("Water" in Figure 7). We conclude that scalping early in the spring when damage is rapidly increasing will not reduce mite damage, but scalping in late spring will reduce damage until next season. Since abamectin is only labeled for application to turfgrass on golf courses, even fewer options are available for residential lawns. Therefore, mechanical control may be a viable option in residential lawns where few effective chemical tools are available. 


\section{Selected References}

Baker, W. E., T. Kono, and N. R. O’Neill. 1986. “Eriophyes zoysiae (Acari: Eriophyidae), a new species of eriophyid mite on zoysiagrass." International Journal of Acarology. 12: 3-6.

Beehag, G. W. 1992. “Couchgrass culture in Australia.” Turf Notes. 11: 10-11.

Buss, E. A. 2008. Bermudagrass Mite. ENY-328. Gainesville: University of Florida Institute of Food and Agricultural Sciences. http://ufdcimages.uflib.ufl.edu/ IR/00/00/28/49/00001/LH03500.pdf.

Buss, E., and A. G. Dale. 2016. Landscape Integrated Pest Management. ENY-298. Gainesville: University of Florida Institute of Food and Agricultural Sciences. http://edis.ifas. ufl.edu/in109.

Casler, M. D., and R. R. Duncan. 2003. Turfgrass Biology, Genetics, and Breeding. pp. 235-256.

Christians, N. E., A. J. Patton, and Q. D. Law. 2017. Fundamentals of Turfgrass Managment. Fifth ed. John Wiley \& Sons, Inc.

Cromroy, H. L. 1983. "Potential use of mites in biological control of terrestrial and aquatic weeds." In Hoy, M. A., G. L. Cunningham, And L. Knutson (eds) Biological control of pests by mites. Univ. Calif. Division Agric. Nat. Resources, Special Pub. 3304: 61-66.

De Lillo, E., and R. Monfreda. 2004. 'Salivary secretions' of eriophyoids (Acari: Eriophyoidea): first results of an experimental model." Experimental and Applied Acarology. 34: 291-306.

Haydu, J. J., A. W. Hodges, and R. C. Hall. 2006. Economic Impacts of the Turfgrass and Lawncare Industry in the United States. FE-632. Gainesville: University of Florida Institute of Food and Agricultural Sciences. http://edis.ifas. ufl.edu/fe632

Jeppson, L. R., H. Keifer, and E. W. Baker. 1975. Mites Injurious to Economic Plants. University of California Press. pp. 333-450.

Johnson, F. A. 1975. "Bermudagrass mite, Eriophyes cynodoniensis Sayed (Acarina: Eriophyidae) in Florida with reference to its injury symptomology, ecology, and integrated control." Ph.D. Dissertation, University of Florida, Gainesville.
Keifer, H. H., E. W. Baker, T. Kono, M. Delfinado, and W. E. Styer. 1982. "An Illustrated Guide to Plant Abnormalities Caused by Eriophyid Mites in North America." United States Department of Agriculture, Agriculture Handbook No. 573 , p. 84.

Kneebone, W. R. 1966. "Bermudagrass-Worldly, Wily, Wonderful Weed." In Proc. Scotts Turfgrass Res. Conf. Vol. 4, Turfgrass Breeding. Ceon. Bot. 20: 94-97.

Reinert, A. J., C. M. Taliaferro, and J. A. McAfee. 2008. "Susceptibility of bermudagrass (Cynodon) varieties to bermudagrass mite (Eriophyes cynodoniensis)." Proc. II IC on Turfgrass. Acta Hort. 783, ISHS, pp. 519-528.

Reinert, J. A. 1983. “The Bermudagrass Stunt Mite.” USGA Green Section Record 20(6): 9-12.

Sabelis, M. W., and J. Bruin. 1996. "Evolutionary ecology: life history patterns, food plant choice and dispersal." In: Lindquist, E. E., M. W. Sabelis, and J. Bruin. (eds) Eriophyd mites: their biology, natural enemies and control. Elsevier Science Publishing, Amsterdam (World Crop Pests, Vol. 6, pp. 329-366).

Salisbury, F. B., and C. W. Ross. 1985. Plant Physiology. Third ed. Wadsworth Publishing Company.

Smith, L., E.. De Lillo, and J. W. Amrine Jr. 2009. "Effectiveness of eriophyid mites for biological control of weedy plants and challenges for future research." Experimental and Applied Acarology. 51: 115-149.

Sternhcht, M., and S. Goldenberg. 1971. "Fertilisation, sex ratio and postembryonic stages of the citrus bud mite Aceria sheldoni (Ewing) (Acarina, Eriophyidae)." Bulletin of Entomological Research. 60: 391-397.

Szczepaniec, A., and M. J. Raupp. 2012. "Effects of Imidacloprid on Spider Mite (Acari: Tetranychidae) Abundance and Associated Injury to Boxwood (Buxus spp.)." Arboriculture \& Urban Forestry. 38: 37-40.

Trenholm, L., J. B. Unruh, and T. W. Shaddox. 2005. Bermudagrass for Florida Lawns. ENH-19. Gainesville: University of Florida Institute of Food and Agricultural Sciences. http://edis.ifas.ufl.edu/lh007

Watschke, T. L., H. P. Dernoeden, and D. J. Shetlar. 1995. Managing Turfgrass Pests. Lewis Publishers.

Wilson, N. S. 1959. "Eight new species of eriophyid." Ann. Am. Entomol. Soc. 52: 141-149. 
Table 1. Insecticides and miticides labeled for bermudagrass mite control in Florida.

\begin{tabular}{|c|c|c|c|}
\hline Active Ingredient & Trade Name(s) & IRAC Class \# & Labeled Use Site* \\
\hline Abamectin & $\begin{array}{l}\text { Divanem, Todal, } \\
\text { Nemamectin }\end{array}$ & 6 & GC \\
\hline Azadirachtin & Azatrol, Neemix, Turplex & $18 \mathrm{~B}$ & $\mathrm{GC}, \mathrm{RL}, \mathrm{NRL}, \mathrm{S}$ \\
\hline Bifenthrin & Talstar, Menace, others & 3 & $\mathrm{GC}, \mathrm{RL}, \mathrm{NRL}, \mathrm{S}$ \\
\hline Chlorpyrifos & Dursban & 1B & $\mathrm{S}$ \\
\hline Deltamethrin & Deltagard & 3 & $\mathrm{GC}, \mathrm{RL}, \mathrm{NRL}, \mathrm{S}$ \\
\hline Dicofol & Kelthane & $2 A$ & S, NRL \\
\hline Lambda-cyhalothrin & Demand, Scimitar & 3 & $\mathrm{GC}, \mathrm{RL}, \mathrm{NRL}, \mathrm{S}$ \\
\hline Z-cypermethrin + Bifenthrin + Imidacloprid & Triple Crown T\&O & $3,4 \mathrm{~A}$ & $\mathrm{GC}, \mathrm{RL}, \mathrm{NRL}, \mathrm{S}$ \\
\hline
\end{tabular}

